\title{
Profitability Analysis of Groundnut Production in Ardo- Kola Local Government Area of Taraba State, Nigeria
}

\author{
Aboki E1., I.I. Umar², D.T. Rukwe 3 and S. yahaya ${ }^{3}$ \\ ${ }^{1}$ Department of Agricultural Economics and Extension, Taraba State University, Jalingo, Nigeria \\ 2Department of Agricultural Economics, University Nigeria, Nsukka, Nigeria \\ ${ }^{3}$ National Agricultural Extension and Research Liaison Services. ABU Zaria \\ *Corresponding Author \\ Aboki E
}

Article History

Received: 20.07.2019

Accepted: 06.08.2019

Published: 16.08 .2019

\begin{abstract}
They study analyzed the profitability of groundnut production in Ardo-kola Local Government Area of Taraba State, Nigeria. Despite the fact that Nigeria has been one of the leading producer of groundnut in the world, the demand for the product to meet up nutritional requirement in the country is still high. The specific objectives of the study were to describe the socio-economic characteristics of groundnut farmers, determine the factors influencing groundnut production, estimate profitability of groundnut production and identify the constraints in groundnut production in the study area. Primary data were collected from 150 groundnut farmers using multi-stage and purposive sampling techniques. The data were analyzed using frequency and mean, farm budgeting techniques and regression analysis. The results revealed that majority $(67 \%)$ of the respondents were male. About $48 \%$ of the respondents were youths of $31-40$ years old, majority (60\%) of the respondents were married while $93 \%$ of the respondents had formal education. The gross margin analysis shows that groundnut farmers incurred a total variable cost of 102,000 , fixed cost of $\$ 33,000$ and a total revenue of $\$ 220,000$. The regression result indicated that 3 variables regressed were statistically significant. The variable $X 1$ and $X 4$ were statistically significant at $1 \%$ level of significance while $X 2$ was statically significant at $5 \%$ level of significance. The result further revealed that the business of groundnut farming is a profitable venture. Based on the finding, it is recommended that farmers should organized themselves into groups for easy access to formal sources of credit to provide needed farm implement and quality seed.
\end{abstract}

Keyword: profitability analysis, groundnut production, regression analysis, statistically significant, budgeting techniques.

\section{INTRODUCTION}

Groundnut Arachishypogea belong to the family leguminosea. It originated from Latin America and Portuguese introduce into West Africa from Brazil in the 16th Century [1]. Groundnut is the 13th most important food crop of the world. It is the world's 4th most important source of edible oil and 3rd most important source of vegetable protein. [2]. Groundnut seeds contain high quality edible oil $(50 \%)$, easily digestible protein $(25 \%)$ and carbohydrate $(20 \%)$. It is grown on 26.4 million ha worldwide with a total production of 36.1 million metric tons, and an average productivity of 1.4 metric tons/ha [3]

Groundnut is grown in nearly 100 countries with China, India, Nigeria, USA, Indonesia and Sudan as major producers. Developing countries accounted for $96 \%$ of the global groundnut area and $92 \%$ of the global production. Asia accounts for $58 \%$ of the global groundnut area and $67 \%$ of the groundnut production with annual growth rate of $1.28 \%$ for area, $2.00 \%$ for production and $0.71 \%$ for productivity. Globally, $50 \%$ of groundnut produce is used for oil extraction, $37 \%$ for confectionery use and $12 \%$ for seed purpose. In India, $80 \%$ of the total produce is used for oil extraction, $11 \%$ as seed, $8 \%$ direct food uses and $1 \%$ is exported. Groundnut haulms (vegetative plant part) provide excellent hay for feeding livestock [ 4 ]

Awoke [5] noted that groundnut is cultivated in many countries and leading producing countries are India, Nigeria, United State, China and Senegal. Nigeria produces $41 \%$ of the total groundnut production in West Africa [6, 1].. Groundnut contains $25 \%$ protein and more than $48 \%$ oil [7]. Hamidu et al [1] observed that groundnut flour is used as an ingredient in soup, confectionaries,

Copyright @ 2019: This is an open-access article distributed under the terms of the Creative Commons Attribution license which permits unrestricted use, distribution, and reproduction in any medium for non commercial use (NonCommercial, or CC-BY-NC) provided the original author and source are credited. 
pudding, groundnut cake (kuli-kuli). Hamidu et al. [1] reported that groundnut is the main export crop of Nigerians Northern States and bulk of the crop is produced at the North on latitude $110 \mathrm{~N}$.

Nigeria has become a net importer of groundnut. Groundnut producers as well as marketers encounter a lot of problem in relation to their activities, the problems include lack of technical know-how in the production practices, storage, marketing or processing. Generally this include lack of adequate storage facilities, pests and diseases infestation, drought, high cost of input, untimely supply of input and poor market price at harvest. These problems affect groundnut production in Ardo-kola local government area.

\section{MATERIALS AND METHODS The Study Area}

The study was carried out in Ardo-kola local government area of Taraba state. Ardo-kola is located in the northern part of the state. The local government area lies between latitude $8030^{\prime \prime}$ and $90010^{\prime \prime}$ of the equator and longitude $10058^{\prime \prime}$ and $11030^{\prime \prime}$ of the Greenwich meridian. The local government areas have a land mass of 3, 268 $\mathrm{km}^{2}$ with a population of 56, 921 [ 8 ] Projected to 165 , 589 in 2016

The local government areas share a common boundary with Jalingo local government area, to the east, Gassol to the west, Karim Lamido to the north and Bali LGA to the south. The climate of the area is marked by dry season between (November-March) and rainy season between (April-October). It has an average annual rainfall ranging between $800 \mathrm{~mm}$ to $1525 \mathrm{~mm}$ and temperature range between $20^{\circ} \mathrm{C}$ to $38^{\circ} \mathrm{C}$.

The local government is predominately agrarian in nature and rich alluvial track of soil found in most part of the local government area are conducive for growing of various food crops, majority of inhabitants of the local government area are engage in family and rearing of animals as an occupation.

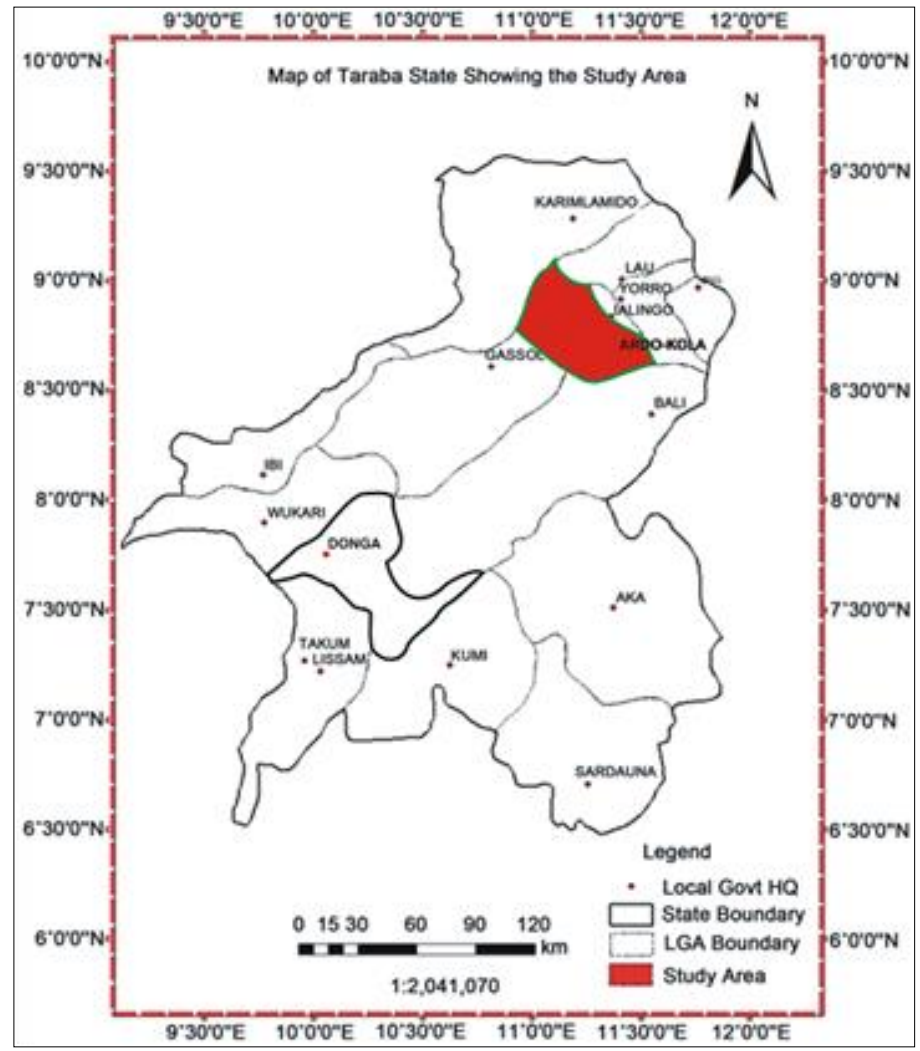

Fig. 01 = Map of Taraba Showing the Study Area

Geography Department 2017

\section{SAMPLING PROCEDURE.}

A multi stage and purposive sampling techniques were employed in this study. Ardo-kola LGA is divided into 10 wards. Firstly five wards were be purposively selected based on their relevance in groundnut production. In the second stage 2 villages were randomly selected from the five wards to give a total of 10 villages. A proportionate sampling technique was used to select 150 farmers in proportion to their population from the selected villages. 


\section{METHOD OF DATA ANALYSIS.}

The researcher employed the use of descriptive statistics, farm budgeting technique and regression analysis. Farm budgeting technique was used to estimate costs and returns of the groundnut production. The regression analysis was used to determine the factor influencing groundnut production while the descriptive statistics was used to address socio economic characteristics. The models are specified below:

\section{Budgeting Technique.}

$\mathrm{GM}=\mathrm{GI}-\mathrm{TVC}$

Where: - GM= Gross Margin.

$\mathrm{GI}=$ Gross Income

TVC $=$ Total variable cost

$\mathrm{NFI}=\mathrm{GM}-\mathrm{TFC}$

Where: $-\mathrm{NFI}=$ Net farm income

TFC = Total Fixed Cost.

To determine the profitability level of groundnut production, some ratios were used as adopted from [9]

$\mathrm{GR}=\mathrm{TC} / \mathrm{GI}$

Where: - GR $=$ Gross Ratio

$\mathrm{TC}=$ Total Cost

Or $\mathrm{TVC} / \mathrm{Gl}=$

Where: - or = operating ratio -

$F R=\underline{T F E}$ OR TC

$\frac{\mathrm{G} 1}{\mathrm{G} 1}$

Where: $-\mathrm{Fr}=$ Fixed Ratio

IFE = Total farm expense

Gross Ratio (GR) less than $(<1)$ was desirable for business. The lower the ratio, the higher the returns per naira invested. A ratio greater than $(>1)$ was disastrous for any set up business. Operating ratio $(O R)$ of one means the gross income barely covers the expense on variables costs. The operating ratio of less than one $(<1)$ was desirable if the fixed ratio $(F R)$ is close to one. It means some of the fixed cost or input were either left idle or under-utilized

\section{Regression Analysis}

Four functional forms were used for the analysis. The four functional forms were:-

Linear Function

Semi-Log

Exponential and

The double-Log.

The regression modes is expressed as follows:

$Y=$ Total output (N/Kilograms)

$X_{1}=$ Seed (N/kilograms)

$X_{2}=$ Fertilizer (N/kilograms)

$X_{3}=$ Labour (N/man-days)

ai $=(i=1-5)=$ regression coefficient

$a_{0}=$ Constant

$\mathrm{u}=$ error term which is assumed to be normally and independently distributed, the linear is based on the assumption that the input and output are all related by straight line which implies that the marginal product of each is constant hence diminishing marginal returns is ruled out. Also, the function assumes constant rate of technical substitution among the inputs.

$Y=b_{0}+b_{1} X_{1}+b_{2} X_{2}+b_{3} X_{3}+b_{4} X_{4}+b_{5} X_{5}$

$b_{0}=$ is Constant and

$X_{1}-X_{5}$ are the variables to be estimated

$b_{1}-b_{5}$ are regression coefficient parameter to be estimated.

\section{RESULTS AND DISCUSSION}

\section{Socio -economic Characteristics of Groundnut Produces}

Result in Table.1 revealed that majority (67\%) of the respondent were male. This means that men dominated groundnut production in Ardo-Kola and Lau Local Government Area. This could be because men are mostly the bread winners of their families coupled with the fact that they are capable of handling the vigorous work involved in groundnut production while the low percentage of women involvement may be explained by socio-cultural factors affecting women such as unequal access and control over land as well as high cost of production inputs. 
Analysis in Table 1 further reveals that $60 \%$ of the respondents were married, this is an indication that married people were more involved in groundnut production in the study area compare to their single counterpart. This finding is in consonance with Afolami et al., [4 ] who found that about $93 \%$ of Oyo states Farmers were married.

Result of the study also revealed that majority (47\%) of the respondents were youths between $31-40$ years, implying that groundnut production in the study area was dominated by youth endowed with adequate energy to tackle the challenges and engage more in the groundnut production to cater for their need. Majority (90\%) of the respondents were literate having at least one form of formal education or the other. This could have a positive impact on adoption of new agricultural innovation. This finding disagrees with that of Girei et al.,[ 10 ] which stated that $60.42 \%$ of farmers in the study conducted in Adamawa State had no formal education. The findings also re1vealed that majority (64\%) of the respondents had family size of $1-3$.

\begin{tabular}{|c|c|c|}
\hline Variables & Frequency & Percentage \\
\hline \multicolumn{3}{|l|}{ Gender distribution } \\
\hline Male & 101 & 67 \\
\hline Female & 49 & 33 \\
\hline Total & 150 & 100 \\
\hline \multicolumn{3}{|l|}{ Marital status } \\
\hline Single & 45 & 30 \\
\hline Married & 90 & 60 \\
\hline Widow & 8 & 5.3 \\
\hline Divorced & 7 & 4.7 \\
\hline Total & 150 & 100 \\
\hline \multicolumn{3}{|l|}{ Age } \\
\hline $21-30$ & 30 & 20 \\
\hline $31-40$ & 72 & 48 \\
\hline $41-50$ & 30 & 20 \\
\hline$\geq 51$ & 18 & 12 \\
\hline Total & 150 & 100 \\
\hline \multicolumn{3}{|l|}{ Educational level } \\
\hline Non formal & 10 & 7 \\
\hline Primary & 31 & 20 \\
\hline Adult education & 60 & 40 \\
\hline Secondary education & 42 & 28 \\
\hline Tertiary education & 7 & 5 \\
\hline Total & 150 & 100 \\
\hline \multicolumn{3}{|l|}{ Family size } \\
\hline $1-3$ & 97 & 64 \\
\hline $4-6$ & 45 & 30 \\
\hline$\geq 7$ & 5 & 6 \\
\hline Total & 150 & 100 \\
\hline
\end{tabular}

\section{Estimate on Factor influencing Groundnut output}

This section examined the extent to which the independent variables (seed, fertilizer, chemical, labour and farm size) explain the variability of the dependent variable (groundnut output). The result of the regression shows that the double log function was the best fit equation based on the number of significant variables and its coefficient of multiple determination for the unit. The three variables $X_{1} X_{2}$ and $X_{4}$ were statistically significant at $1 \%$ level of probability. The $R^{2}$ value obtained is 0.79 . This indicated that about 79 percent of the variation in the output of groundnut were explained by the independent variables $X_{1}, X_{2}$ and $X_{4}$. The unexplained variation in groundnut output is obviously due to other inputs not specified in the model. The F- ratio value obtained is 80.63 .

The regression coefficient show the extent to which variation in independent variables explains variation in the dependent variable. The $t$ - values were used to test the significance of the coefficient. The regression coefficients of production with respect to the $X_{1}$ and $X_{4}$ are 0.181275 and 181.4094 respectively. These values are significant at $1 \%$ level respectively.. This implies that a $1 \%$ increase in the seed $\left(X_{1}\right)$ and labour $\left(X_{4}\right)$ will lead to an increase in the output of groundnut by 0.181275 and 181.4094 percent respectively. Fertilizer $\left(X_{2}\right)$ is significant at $5 \%$ level of significance this implies that increase in the level of fertilizer application will lead to increase in the output of groundnut by 0.361302 ceteris paribus. 
Table-2: Factors Influencing Groundnut Production.

\begin{tabular}{|l|l|l|l|}
\hline Valuable & Co-efficient & Standard Error & T Value \\
\hline C & 5.879680 & 0.187160 & 29.81239 \\
\hline X1 & 0.181275 & 0.043882 & $4.1310^{*}$ \\
\hline X2 & 0.361302 & 0.12727 & $2.9927^{\text {** }}$ \\
\hline X3 & 0.155433 & 0.119549 & $1.300163 \mathrm{NS}$ \\
\hline X4 & 181.4094 & 49.27460 & $3.681600^{*}$ \\
\hline X5 & 67.18238 & 59.92562 & $1.12110 \mathrm{NS}$ \\
\hline
\end{tabular}

Source: Field survey 2017.

${ }^{*}$ Significant at $1 \%{ }^{* *}$ Significant at $5 \%, \mathrm{R}^{2}=79.79, \mathrm{~F}=80.63$

\section{Average Cost and Returns of Groundnut Production}

The gross margin was obtained by subtracting the variable costs from the total revenue, while the net farm income was obtained by subtracting fixed cost elements from the gross margin. The total variable cost was one hundred and two thousand naira


thousand naira. The farmer's average rate of return from groundnut production was 0.63 meaning that for every naira a groundnut farmer spent in the study area he/she will gain six three kobo. This shows that the business of groundnut production in the study area is a profitable venture.

Table-3: Gross Margin Analysis of groundnut Production in the Study Area

\begin{tabular}{|l|l|}
\hline Production Variables & Value in (A/ha) \\
\hline A. & Cost \\
\hline Seed & 10,000 \\
\hline Fertilizer & 20,000 \\
\hline Chemical & 5,000 \\
\hline Ploughing & 25,000 \\
\hline Transportation & 6,000 \\
\hline Bagging & 9,000 \\
\hline Weeding & 17,000 \\
\hline Threshing & 10,000 \\
\hline Total veraible cost & 102,000 \\
\hline B. & Fixed Cost \\
\hline Hoe & 3,000 \\
\hline Wheelbarrow & 10,000 \\
\hline Cutlass & 5,000 \\
\hline Sprayer & 15,000 \\
\hline T F C & $\mathbf{3 3 , 0 0 0}$ \\
\hline TC $=($ TVC +TFC) $=$ & 135,000 \\
\hline C.Total Revenue: & \\
\hline
\end{tabular}

C.Total Revenue:

Average output $\mathrm{kg} / \mathrm{ha}=2000 \mathrm{~kg}$

Average price of Groundnut $=\$ 101 \mathrm{~kg}$

Total Revenue: $=$ N 220, 000

Gross Merging $(\mathrm{GM})=\mathrm{TR}-\mathrm{TVT}=118,000$

Net Farm Income $=\mathrm{GM}-\mathrm{TFC}=85,000$

Average rate of return (ARR) NFI/TC $=0.63$

Source: Field Survey, 2017

\section{CONCLUSION}

It can therefore be concluded that farm profitability can be improved if input are purchased at low costs or output sold at higher prices in addition to address major constraints identified in the study area. Groundnut production among farmers was found to be profitable.

\section{RECOMMENDATIONS}

Based on the findings the following recommendations were made to boast groundnut production:

1. Farmers need to organize themselves into groups for easy access to formal sources of credit to acquire the needed farm implements, quality seeds etc. 
2. Also more efforts should be intensified on the part of extension agents in educating the farmers so as to boost their efficiencies in maize production.

3. Use of improved varieties of groundnut seeds and mechanized labour should be encourage and made available to the farmers at the right time.

\section{REFERENCES}

1. Hamidu, B. M., Kuli, S. G., \& Mohammed, I. (2006, September). Profitability analysis of groundnut (Arachis Hypogae L.) processing among women enterprenuers in Bauchi Metropolis. In A paper presented at the Farm Management Association of Nigeria Proceedings of 20th Annual National Conference (pp. 387-391).

2. Smith, A. F. (2002). Peanuts: The illustrious history of the goober pea (Vol. 20). University of Illinois Press.

3. luss, I. (2006). FAO, 2006. World base reference for soil resources. Report on World Soil Resources. FAO. Rome, Italy.

4. Afolami, C. A. Obayelu, A. E; Agbonlahor. Mu. And lawal - Adebowake, O. A. (2017). Socioec-onomic Analysis on groundnutfarmers and effects of group formation on Groundnut productionr in Ekiti and Ogun state of South - West Nigeia.

5. Awoke, M. U. (2003). Production analysis of groundnut,(arachis hypogaea) in Ezeagu local government area of Enugu state, Nigeria. Global Journal of Agricultural Sciences, 2(2), 138-142.

6. Abalu, G. O. I., \& Etuk, E. G. (1986). Traditional versus improved groundnut production practices: some further evidence from Northern Nigeria. Experimental agriculture, 22(1), 33-38.

7. Echekwu, C. A., \& Emeka, I. (2005). Groundnut, endowing, the groundnut/rediscovery programme in Nigeria. Opah mission Abuja, 18.

8. National Population Commision, Preliminary (2006) Census figures. Retrieved 2007 from http//www.population.gov.ng/pop-figure.

9. Olukosi, J. O., \& Erhabor, P. O. (1988). Introduction to farm management economics: principles and applications. Agitab: Zaria.

10. Girei, A. A., Dauna, Y., \& Dire, B. (2013). An economic analysis of groundnut (Arachis hypogea) production in Hong local government area of Adamawa State, Nigeria. Journal of Agricultural and Crops Research, 1(6), 84-89. 